\title{
GAMBARAN SISTEM MANAJEMEN DALAM BIMBINGAN DAN KONSELING SEKOLAH MENENGAH ATAS
}

\author{
Nina Fitriyani \\ Program Pasca Sajana Bimbingan dan Konseling, Fakultas Pendidikan, Universitas Negeri Jakarta \\ ninafitriyani_bk18s2@mahasiswa.unj.ac.id \\ Herdi \\ Program Pasca Sajana Bimbingan dan Konseling, Fakultas Pendidikan, Universitas Negeri Jakarta \\ herdi@unj.ac.id
}

\begin{abstract}
Abstrak:
Tujuan dari penelitian ini adalah untuk mengetahui gambaran system manajemen dalam bimbingan dan konseling sekolah menengah atas (SMA). Metode yang digunakan dalam penelitian ini adalah metode deskriptif bentuk survey. Penulis mengadakan survey ke beberapa SMA yang terdiri dari 2 Sekolah Menengah Atas Negeri dan 2 Sekolah menengah atas Swasta.. Instrumen yang digunakan menggunakan skala likert. Hasil dari penelitian menunjukkan bahwa audit program system manajemen dalam bimbingan dan konseling di SMA Negeri dan Swata dapat diketahui dari hasil penelitian bahwa: penilaian terhadap system manajemen dari keseluruhan sekolah termasuk dalam kategori baik dengan skor 65\%. Hasil penelitian ini disarankan agar dinas pendidikan setempat supaya memberikan tindak lanjut terkait pelaksanaan dan audit penyusunan program bukan hanya dari program system manajemennya saja tetapi program bimbingan dan konseling komprehensif di sekolah menengah atas secara menyeluruh.
\end{abstract}

Kata Kunci: Audit Program, system manajemen bimbingan dan konseling

\begin{abstract}
:
The purpose of this research is to know the description of the management system in the guidance and counseling high school (HIGH SCHOOL). The methods used in this research is descriptive method is a form of survey. The authors held a survey to several high school consists of 2 public High Schools and 2 Private high school The instruments used to use the likert scale. The result of the research shows that the audit program management system in guidance and counseling at SMA Negeri and known Swata from research results that: assessment of the management system of the whole school is included in the category of good with a score of $65 \%$. The results of this research it is recommended that the local education Office so that provide related follow-up implementation and audit preparation programs not just from program management system alone but a comprehensive guidance and counseling program in school medium top thoroughly.
\end{abstract}

Keywords: Audit Program, the management system of guidance and counseling

\section{PENDAHULUAN}

Peserta didik adalah sebagai subjek utama dalam ruang lingkup pendidikan, peserta didik bukan hanya dipandang sebagai subjek tetapi sebagai objek sekaligus. sebagai objek peserta didik harus dapat difasilitasi untuk mencapai tugas-tugas perkembangannya dalam mencapai optimalisasi diri baik yang menyangkut aspek kogntif, afektif dan psikomotorik. Peserta didik memiliki kemampuan-kemampuan yang dapat dikembangkan, kebutuhan jasmani dan rohani juga harus terpenuhi. Menurut Yusuf (2009) bahwa bidang pengajaran dan administrasi belum mampu cukup memberikan pelayanan kepada peserta didik, maka dibutuhkan bidang lain yang khusus memperhatikan perkembangan siswa masingmasing, bidang itu adalah bidang bimbingan dan konseling.

Dalam layanan bimbingan dan konseling terdapat program sekolah yang harus dilaksanakan untuk diberikan kepada peserta didik dalam membantu tercapainya tujuan pendidikan yang sesuai. Program bimbingan dan konseling di sekolah mewadahi seluruh rangkaian kegiatan bimbingan dan konseling yang akan diberikan kepada peserta didik harus mampu menunjang tercapainya visi/misi yang ada di sekolah.

Merancang program bimbingan dan konseling harus didasarkan pada pedoman kurikulum dan juga berdasarkan kondisi objektif yang sesuai dengan kebutuhan sekolah yang disesuaikan dengan tahapan perkembangan peserta didik. Menurut Kurniawan (2015) bimbingan dan konseling yang bermakna adalah bimbingan dan konseling yang memberikan manfaat bagi pesera didik, oleh karena itu layanan bimbingan dan konseling hendaknya berdasarkan pada kebutuhan peserta didik.

Menurut Ratnasari \& Herdi (2018) program layanan bimbingan dan konseling dirancang berdasarkan analisis kebutuhan peserta didik yang ada dalam layanan dasar bimbingan, layanan responsive, layanan perencanaan individual dan dukungan system. Tercapainya program yang efektif dan optimal akan 
membentuk karakter moral peserta didik yang berakhlak. Oleh karena itu butuhkan peran dan kinerja yang lebih maksimal dan optimal dari layanan yang diberikan oleh konselor terhadap peserta didik

Tujuan utama dalam layanan bimbingan dan konseling adalah memberikan dukungan pencapaian kematangan kepribadian, keterampilan sosial, kemampuan akademik, dan berakhir pada terbentuknya kematangan karir peserta didik yang diharapkan dapat bermanfaat untuk masa yang akan datang Rahman (2009). Namun demikian, implementasi layanan bimbingan dan konseling yang ideal tersebut berhadapan dengan berbagai hambatan dan kendala, seperti tujuan bimbingan dan konseling tidak selaras dengan tujuan pendidikan, bimbingan dan konseling masih berorientasi pada masalah peserta didik, penyusunan program belum berdasarkan need assessment, minimnya dukngan dan pejabat sekolah dan belum adanya pemahaman paradigm mengenai pentingnya kolaborasi antar profesi dalam satuan pendidikan dan kurang adanya respon positif dari peserta didik terhadap layanan bimbingan dan konseling.

Optimalisasi pelayanan bimbingan dan konseling perlu dilakukan sehingga pelayanan bimbingan dan konseling benar-benar memberikan kontribusi pada visi/misi dan tujuan sekolah yang sudah ditetapkan kegiatan ini didukung oleh manajemen pelayanan yang baik guna tercapainya peningkatan mutu pelayanan bimbingan dan konseling pada prinsipnya manajemen memuat makna segala upaya menggerakkan individu atau kelompok untuk bekerja sama dalam mendayagunakan sumber daya dalam suatu system untuk mencapai tujuan. Apabila diterapkan dalam bimbingan dan konseling adalah segala upaya atau cara yang digunakan untuk mendayagunakan secara optimal semua komponen atau sumber daya seperti tenaga, dana, sarana/prasarana dan system informasi berupa data himpunan data bimbingan untuk menyelenggarakan pelayanan bimbingan dan konseling dalam rangka mencapai tujuan.

Zamroni \& Rahardjo (2015) prinsip-prinsip manajemen pelayanan bimbingan dan konseling meliputi : planning, organizing, staffing, leading \& controlling. Manajemen bimbingan dan konseling merupakan salah satu kompetensi dasar yang harus dikuasai oleh seorang konselor. Manajemen bimbingan dan konseling yang terarah daan sistematis merupakaan perwujudan dan penghimpunan pelayanan bimbingan dan konseling yang merupakan indikator kerja konselor. Selanjutnya dengan manajemen bimbingan dan konseling yang sistematis dan terarah yang baik pada gilirannya akan memberikan paduan pelaksanaan kegiatan bimbingan dan konseling sekaligus menghilangkan kesan bahwa konselor bekerja secara insidental dan kuratif saja.

Sehubungan dengan konsep manajemen maka implementasi manajemen bimbingan dan konseling merupakan salah satu manifestasi suatu kegiatan yang sitematis tentang bagaimana merencanakan suatu aktivitas bimbingan dan konseling untuk mencapai tujuan, mengawasi bagaimana kegiatan bimbingan dan konseling berjalan dan menilai kegiatan bimbingan dan bimbingan dan konseling. Berdasarkan hal tersebut, maka implementasi pelaksanaan manajemen bimbingan dan konseling sekolah yang kaitannya dengan proses perencanaan, perorganisasian, pelaksanaan, memimpin dan pengawasan dapat terlaksana.

$\begin{array}{ccr}\text { Manajemen Bimbingan dan Konseling } & \\ \text { Menurut Rahim } & (2013) & \text { mendefinisikan } \\ \text { manajemen merupakan proses perencanaan, }\end{array}$ pengorganisasian, kepemimpinan dan pengendalian semua sumber daya dalam organisasi untuk mencapai tujuan yang telah ditetapkan. Menurut Rahim (2013) mendefinisikan manajemen adalah sebagian kemampuan atau skill seseorang untuk memperoleh suatu hasil dalam rangka mencapai tujuan melalui kegiatan orang lain. Dalam ensiklopedi Ekonomi, Bisnis dan Manajemen dijelaskan bahwa manajemen merupakan proses merencanakan dan mengambil keputusan, mengorganisasikan, memimpin dan mengendalikan sumber daya manusia, keuangan, fasilitas dan informasi guna mencapai sasaran organisasi dengan efisien dan efektif.

Dari pengertian diatas dapat disimpulkan bahwa manajemen adalah suatu keseluruham proses kerjasama yang memanfaatkan semua sumber daya (ketenagaan, dana, sarana prasarana dan informasi) yang tersedia dan sesuai untuk mencapai tujuan pendidikan yang telah ditetapkan secara efektif dan efisien. Menurut Kristiawan, Safitri \& Lestari, (2017) manajemen pendidikan adalah suatu kegiatan atau rangakaian kegiatan yang berupa proses pengelolaan usaha kerja sama antar sesama kelompok yang tergabung dalam organisasi pendidikan guna untuk mencapai tujuan pendidikan yang telah ditetapkan sebelumnya. Dengan memanfaatkan sumber daya yang ada dan menggunakan fungsi-fungsi manajemen agar tercapainya tujuan secara efektif dan efisien.

Berdasarkan dari berbagai definisi manajemen diatas, maka dapat dirumuskan manajemen bimbingan dan konseling sebagai aktivitas memadukan sumberdayasumberdaya bimbingan dan konseling dalam upaya mencapai tujuan pendidikan pada umumnya dan tujuan bimbingan dan konseling pada khususnya. Bimbingan dan konseling mencakup sebagai salah satu sub system dari ketiga sub sistem dalam proses pendidikan. Memiliki berbagai sumber daya baik berupa tenaga kerja, dana, sarana dan prasarana. Maka dari itu dibutuhkan pengelolaan terhadap sumber daya agar dapat tercapai secara optimal dari tujuan bimbingan dan konseling di sekolah tersebut, yang selanjutnya dapat mengoptimalkan juga pencapaian dari tujuan pendidikan.

Menurut ASCA (2012) dalam sistem manajemen, konselor sekolah memasukkan penilaian dan alat-alat organisasi yang konkret, digambarkan dengan jelas dan mencerminkan kebutuhan sekolah. Penilaian dan alat meliputi:

1. Kompetensi konselor sekolah dan penilaian program konseling sekolah untuk mengevaluasi diri sendiri bidang kekuatan dan peningkatan untuk keterampilan individu dan kegiatan program

2. Gunakan penilaian waktu untuk menentukan jumlah waktu yang dihabiskan menuju $80 \%$ yang 
direkomendasikan atau lebih dari waktu yang dihabiskan oleh konselor sekolah untuk mengarahkan dan layanan tidak langsung dengan peserta didik

3. Perjanjian tahunan dikembangkan dan disetujui oleh administrator pada awal tahun sekolah membahas bagaimana program konseling sekolah diatur dan tujuan apa yang akan dicapai

4. Dewan penasihat terdiri dari peserta didik, orang tua, guru, konselor sekolah, administrator dan anggota masyarakat untuk meninjau dan membuat rekomendasi tentang kegiatan dan hasil program konseling sekolah.

5. Menggunakan data untuk mengukur hasil program serta untuk mempromosikan perubahan sistematik dalam system sekolah sehingga setiap peserta didik lulus ke perguruan tinggi dan siap memilih karir

6. Kurikulum, kelompok kecil dan rencana aksi penutupan kesenjangan di Indonesia termasuk kegiatan pengembangan, pencegahan, intervensi dan layanan yang mengukur kompetensi peserta didik yang diinginkan dan dampaknya pada prestadi, perilaku dan kehadiran.

Kegiatan-kegiatan yang harus dilakukan oleh untuk seorang konselor sekolah meliputi: 1) merencanakan program akademik peserta didik; 2) menafsirkan tes kognitif, bakat dan prestasi; 3) memberikan konseling kepada peserta didik yang terlambat atau yang tidak hadir; 4) memberikan konseling kepada peserta didik yang memiliki masalah 5) memberikan konseling kepada peserta didik mengenai tata cara berpakaian disekolah; 6) berkolaborasi dengan guru untuk mempersiapkan inti kurikulum konseling sekolah; 7) menganalisis rata-rata poin dan menghubungkannya dengan prestasi dalam catatan peserta didik; 8) guru memberikan saran untuk manajemen kelas yang efektif; 9) memastikan catatan peserta didik sesuai peratura negara; 10) membantu kepala sekolah mengidentifikasi dan menyelesaikan masalah peserta didik 11) menyediakan layanan konseling ndividu dan kelompok kepada peserta didik; 12) mengadvokasi peserta didik pada perencanaan pendidikan, dari akademik dan kehadiran peserta didik disekolah; 13) menganalisis data terpilah 14) bertugas mengentri data; 15) membuat kalender tahunan dan mingguan untuk memberi informasi kepada peserta didik, orang tua, guru dan administrator dan untuk mendorong partisipasi aktif dalam program konseling sekolah.

Menurut Permendikbud Nomor 111 (2014) pelayanan bimbingan dan konseling komprehensif mempunyai komponen dan strategi layanan yang dilakukan oleh seorang konselor sekolah dapat diuraikan sebagai berikut:

1. Layanan dasar adalah sebagai proses pemberian bantuan kepada seluruh konseli melalui penyiapan pengalaman terstruktur secara klasikal atau kelompok yang dirancang dan dilaksanakan secara sistematis dalam ranga mengembangkan kemampuan penyesuaian diri yang efektif sesuai dengan tahap dan tugas-tugas perkembangan (yang dituangkan sebagai standar kompetensi kemandirian peserta didik). Strategi layanan dalam komponen program ini adalah bimbingan klasikal, bimbingan kelompok, layanan orientasi, layanan informasi, pengumpulan data.

2. Perencanaan individual dan peminatan peserta didik adalah program kurikuler yang disediakan untuk mengakomodasi pilihan minat, bakat kemampuan peserta didik/konseli dengan orientasi pemusatan, perluasan, pendalaman mata pelajaran/muatan kejuruan. Strategi layanannya adalah penilaian individual, bantuan individu/kelompok dalam merencanakan tujuan, melakukan kegiatan dan mengevaluasi, penempatan/penjuruan/penyaluran.

3. Pelayanan responsif adalah pemberian bantuan kepada peserta didik/konseli yang sedang menghadapi masalah dan memerlukan pertolongan dengan segera, agar peserta didik/konseli tidak mengalami hambatan dalam proses pencapaian tugas-tugas perkembangannya. Strategi layanan responsive antara lain konseling individual, konseling kelompok, konsultasi, kolaborasi, kunjungan rumah dan alih tangan kasus (referal). Strategi layanan pada komponen program ini adalah konsultasi, konseling individual/kelompok, konferensi kasus, referral dan bimbingan teman sebaya.

4. Dukungan system adalah komponen pelayanan dan kegiatan manajemen, tata kerja, infrastruktur (misalnya Teknologi Informasi dan Komunikasi), pengembangan kemampuan professional konselor atau guru bimbingan dan konseling secara berkelanjutan, yang secara tidak langsung memberikan bantuan kepada peserta didik/konseli atau memfasilitasi kelancaran perkembangan peserta didik/konseli dan mendukung efektivitas dan efisiensi pelaksanaan layanan bimbingan dan konseling. Kegiatan program ini adalah pengembangan professional, manajemen program dan penelitian.

\section{METODE}

Sesuai dengan tujuan penelitian yaitu untuk memperoleh gambaran mengenai keadaan objek penelitian seperti apa adanya, maka penulis memilih untuk menggunakan penelitian dengan metode deskriptif. Menurut Nazir (2011) metode deskriptif merupakan suatu metode dalam meneliti status kelompok manusia, suatu objek, bagian kondisi, sistem pemikiran, ataupun suatu kelas peristiwa pada masa sekarang dengan tujuan membuat deskripsi, gambaran, lukisan secara sistematis, faktual, dan akurat mengenai fakta-fakta, sifat, serta hubungan antar fenomena yang sedang diteliti.

Sejalan dengan metode peneltian yang digunakan diatas yatu metode deskriptif, maka perlu 
dipilih bentuk penelitian. Tujuan agar dapat memperoleh hasil penelitian yang tepat dan akurat. Adapun bentuk penelitian ini adalah studi survey. Dengan demikian penelitian ini dilaksanakan dengan mengadakan survey ke beberapa Sekolah Menengah Atas (SMA) yang ada di Kota Cilegon antara lain: 1) SMAN 3 Cilegon; 2) SMAN 1 Cilegon; 3) SMA Islam Al Azhar 6 Cilegon; 4) SMA Al-Ishlah Cilegon. Instrumen yang digunakan menggunakan skala likert untuk menggambarkan Sistem Manajemen Dalam Bimbingan dan Konseling Sekolah Menengah Atas.

\section{HASIL DAN PEMBAHASAN}

Berdasarkan hasil penelitian mengenai Gambaran Sistem Manajemen dalam Bimbingan dan Konseling Sekolah Menengah Atas yang telah dilakukan peneliti dapat dijelaskan pada grafik berikut:

Tabel 1. Presentase Sistem Manajemen dalam BK

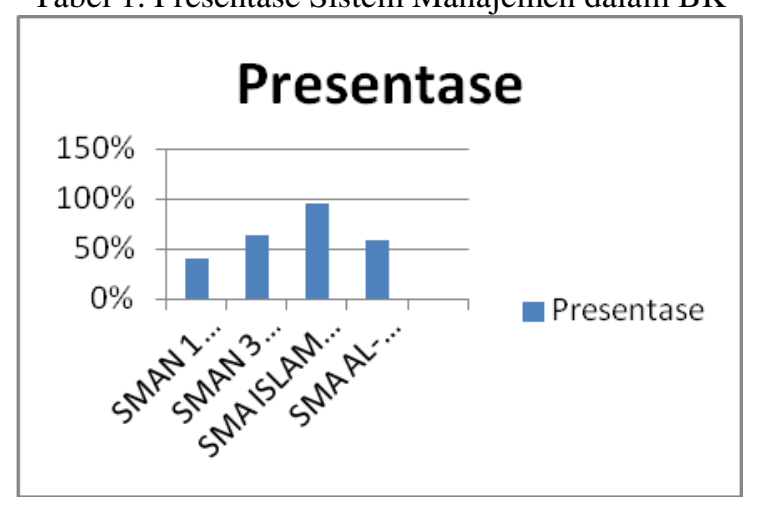

Berdasarkan grafik diatas dapat dijelaskan bahwa penilaian terhadap system manajemen dari keseluruhan sekolah termasuk dalam kategori baik dengan skor $65 \%$. Dengan Rincian yang telah dilakukan oleh peneliti terhadap guru BK di sekolah dapat diketahui dari hasil penelitian bahwa: SMA Negeri 1 Cilegon dengan memperoleh skor 62 dengan persentase $41 \%$ berada pada kategori (cukup baik), SMA Negeri 3 Cilegon memperoleh skor 98 dengan persentase $64 \%$ berada pada kategori (baik), SMA Islam Al-Azhar 6 Cilegon memperoleh skor 146 dengan persentase $86 \%$ berada pada kategori (baik), SMA Al-Ishlah Cilegon memperoleh skor 89 dengan persentase $59 \%$ berada pada kategori (baik).

Dari keempat SMA yang terdiri dari dua SMA Negeri dan 2 SMA Swasta tersebut dapat diperoleh hasil perhitungan secara kuantitatif diatas, pelaksanaan audit program system manajemen dalam bimbingan dan konseling di SMA Cilegon bahwa ada sekolah yang mempunyai kelengkapan program bk dengan baik berdasarkan administrasi dan ada pula sekolah yang belum mempunyai kelengkapan program bk secara lengkap. Kemudian beberapa sekolah sudah melaksanakan program yang sudah dirancang dengan baik dan ada pula sekolah akibat adanya beberapa hambatan namun sudah melaksanakan program bk yang telah dirancang.

Hambatan yang dimiliki oleh salah satu sekolah yaitu tidak adanya dukungan dan kerjasama dari stakeholderyang ada di sekolah dan tidak adanya keterbukaan mengenai manajemen bimbingan dan konseling. Namun ada beberapa sekolah yang memiliki hubungan baik dan kerja sama antara stakeholder serta sudah mendapatkan dukungan yang terdiri dari fasilitas yang memadai, adanya koordinasi dengan konselor dan konselor berpengalaman.

\section{PENUTUP}

Simpulan

Berdasarkan hasil penelitian dapat diambil kesimpulan bahwa pelaksanaan audit program system manajemen dalam bimbingan dan konseling tingkat SMA di Cilegon cukup baik yang ditunjukan dengan berdasarkan data kuantitatif secara umum skor $65 \%$. Dengan rincian SMA Negeri 1 Cilegon dengan memperoleh 62 dengan persentase $41 \%$ berada pada kategori (cukup baik), SMA Negeri 3 Cilegon memperoleh 98 dengan persentase $64 \%$ berada pada kategori (baik), SMA Islam Al-Azhar 6 Cilegon memperoleh 146 dengan persentase $86 \%$ berada pada kategori (baik), SMA Al-Ishlah Cilegon memperoleh 89 dengan persentase $59 \%$ berada pada kategori (baik).

\section{Saran}

Dengan adanya penelitian ini penulis berharap dan menyarankan bagi dinas pendidikan setempat supaya memberikan tindak lanjut terkait pelaksanaan dan audit penyusunan program bukan hanya dari program system manajemennya saja tetapi program bimbingan dan konseling komprehensif di sekolah menengah atas di Cilegon secara menyeluruh. Sehingga program bimbingan dan konseling yang optimal, efektif dan produktif dapat terus berjalan dan berkembang. Diharapkan juga untuk guru bimbingan dan konseling atau konselor sekolah dapat bekerja sama dan membangun komunikasi yang baik dengan para stakeholder sehingga dapat membantu kelancaran kinerja guru bimbingan dan konseling di sekolah

\section{DAFTAR PUSTAKA}

ASCA. (2012). The ASCA National Model : A Framework For School Counseling Programs. New York: Alexandira VA.

Herdi, R. \&. (2018). Kinerja Konselor Dalam Pelaksanaan Manajemen Program Bimbingan Dan Konseling Berbasis Asca Nasional. Jurnal Penelitian Bimbingan dan Konseling , 134-142.

Kurniawan, L. (2015). Pengembangan Program Layanan Bimbingan Dan Konseling Komprehensif DI SMA. Jurnal Psikologi Pendidikan dan Konseling , 1-8. 
Kristiawan, M., Safitri, D., \& Lestari, R. (2017).

Manajemen Pendidikan. Yogyakarta: Deepublish.

Nazir, M. (2011). Metode Penelitian. Bogor: Ghalia Indonesia.

Permedikbud, Nomor. 111. (2014). Tentang Bimbingan dan Konseling Pada Pendidikan Dasar dan Pendidikan Menengah. Jakarta: kemdikbud.

Rahim, M. (2013). Manajemen Bimbingan Dan Konseling Dalam Konteks Manajemen Pendidikan Di Sekolah. Scholar .

Rahman, F. (2009). Bimbingan dan Konseling Komprehensif; Dari Paradigma Menuju Aksi. Disampaikan pada Workshop Penyusunan Program BK Komprehensif bertempat di Ruang Sidang Utama Rektorat UNY, Kerjasama Prodi BK UNY dan PD ABKIN DIY. Yogyakarta: Universitas Negeri Yogyakarta.

Ratnasari. (2018). Kinerja Konselor Dalam Pelaksanaan Manajemen Program Bimbingan Dan Konseling Berbasis Asca Nasional. Jurnal Penelitian Bimbingan dan Konseling , 134-142.

Yusuf, S. (2009). Program Bimbingan dan Konseling di Sekolah. Bandung: Rizqi Press.

Zamroni, E., \& Rahardjo, S. (2015). Manajemen Bimbingan Dan Konseling Berbasis Permendikbud Nomor 111 Tahun 2014. Jurnal Konseling Gusjigang , 1-11. 